\title{
Komentarz do art. 22-23 ustawy z dnia 9 czerwca 2011 r. Prawo geologiczne i górnicze
}

Art. 22.

1. Koncesji na:

1) poszukiwanie lub rozpoznawanie złóż kopalin, o których mowa w art. 10 ust. 1, z wyłączeniem zlóż węglowodorów,

1a) poszukiwanie lub rozpoznawanie kompleksu podziemnego składowania dwutlenku węgla,

2) wydobywanie kopalin, o których mowa w art. 10 ust. 1, ze złóż,

2a) poszukiwanie i rozpoznawanie złóż węglowodorów oraz wydobywanie węglowodorów ze złóż,

3) wydobywanie kopalin ze złóż znajdujących się w granicach obszarów morskich Rzeczypospolitej Polskiej,

4) podziemne bezzbiornikowe magazynowanie substancji,

5) podziemne składowanie odpadów,

6) podziemne składowanie dwutlenku węgla

- udziela minister właściwy do spraw środowiska.

2. Koncesji na wydobywanie kopalin ze złóż, jeżeli jednocześnie są spełnione następujące wymagania:

1) obszar udokumentowanego złoża nieobjętego wlasnością górniczą nie przekracza 2 ha,

2) wydobycie kopaliny ze złoża w roku kalendarzowym nie przekroczy $20000 \mathrm{~m}^{3}$, 
3) działalność będzie prowadzona metodą odkrywkową oraz bez użycia środków strzałowych

— udziela starosta.

3. Przedsiębiorca, który otrzymał od starosty koncesję na wydobywanie kopaliny ze złoża przylegającego do złoża już objętego koncesją udzieloną temu samemu przedsiębiorcy na ten sam rodzaj dzialalności, może rozpocząć wydobywanie kopaliny nie wcześniej niż w dniu, w którym decyzja stwierdzająca wygaśnięcie koncesji wcześniejszej stanie się ostateczna.

4. W zakresie nieokreślonym w ust. 1 i 2 koncesji na wydobywanie kopalin ze złóż udziela marszałek województwa.

Komentowany artykuł określa właściwość rzeczową organów koncesyjnych. Przede wszystkim o ile ustawa nie stanowi inaczej, organem koncesyjnym jest marszałek województwa. Oznacza to, że domniemywa się jego właściwość rzeczową jako organu koncesyjnego. Wprawdzie kompetencje ministra właściwego do spraw środowiska dotyczą problematyki o kluczowym znaczeniu gospodarczym, to jednak, podobnie jak w odniesieniu do starosty, mają charakter wyjątkowy.

Właściwość organu administracji publicznej to w istocie jego zdolność prawna do podejmowania działań w określonych kategoriach spraw oraz w określonych formach prawnych. Jej przestrzeganie, na każdym etapie postępowania, należy do kluczowych obowiązków wszystkich organów administracji (art. 19 k.p.a.). Jeżeli podanie (wniosek) złożono do organu niewłaściwego w sprawie, jego obowiązkiem jest niezwłoczne przekazanie go organowi właściwemu, o czym należy powiadomić wnioskodawcę. Zawiadomienie w tej sprawie musi zawierać uzasadnienie (art. $65 \S 1$ k.p.a.). Decyzja podjęta z naruszeniem przepisów o właściwości obarczona jest wadą nieważności (art. $156 \S 1$ pkt 1 k.p.a.). Przepisy wyznaczające właściwość organu administracji muszą być interpretowane w sposób ścisły.

Komentowany art. 22 pr.g.g. nie jest jednak wolny od wątpliwości. Przykładem może być złoże kopaliny innej niż wymieniona w art. 10 ust. 1 pr.g.g., zlokalizowane częściowo na obszarze lądowym a częściowo na obszarze morskim. W konsekwencji projektowany obszar górniczy może obejmować zarówno część lądową, jak i obszar morski. Nie sposób zakładać, że koncesja na wydobywanie takiego złoża miałaby być wydawana przez dwa organy koncesyjne, tj. marszałka województwa oraz ministra. Zdaniem NSA „w sytuacji gdy część obszaru górniczego - objętego wnioskiem o udzielenie koncesji na wydobywanie złoża kopalin - (bez względu jaki procentowy jest to udział w całym obszarze górniczym) znajduje się w obszarze morskim Rzeczypospolitej Polskiej, zastosowanie będzie miał art. 22 ust. 1 pkt 3 ustawy Prawo geologiczne i górnicze", a w konsekwencji organem koncesyjnym będzie minister właściwy do spraw środowiska (wyrok z dnia 8 kwietnia 2014 r., II GW 1/14). 
Wedle ustawy z dnia 21 marca 1991 r. o obszarach morskich Rzeczypospolitej Polskiej i administracji morskiej ${ }^{1}$ wspomnianymi obszarami są:

- morskie wody wewnętrzne,

- morze terytorialne,

- strefa przyległa,

— wyłączna strefa ekonomiczna (art. 2 ust. 1).

Problemem mogą być złoża wielosurowcowe, tj. takie, w których występują zarówno kopaliny wymienione $\mathrm{w}$ art. 10 ust. 1 pr.g.g. (a więc koncesjonowane przez ministra), jak i pozostałe (a więc koncesjonowane w zasadzie przez marszałka województwa). Wypada opowiedzieć się za ustaleniem wspomnianej właściwości, wskazując na tę kopalinę, która w dokumentacji geologicznej określona zostanie jako główna.

Kolejny problem może wiązać się z właściwością miejscową marszałków województw oraz starostów. W zasadzie obejmuje ona przestrzeń objętą granicami województw bądź powiatów. Jeżeli projektowany obszar górniczy wykracza poza takie granice, właściwy będzie ten organ koncesyjny (odpowiednio marszałek województwa bądź starosta), na obszarze właściwości którego znajduje się większa część nieruchomości objętej wnioskiem koncesyjnym (art. 21 $\S 1$ pkt 1 k.p.a.). Literalnie rzecz biorąc rozwiązanie to zakłada, że postępowanie ma dotyczyć jednej nieruchomości gruntowej, chociaż projektowany obszar górniczy może obejmować więcej nieruchomości. Pomimo iż przepisy wyznaczające właściwość organów administracji podlegają wykładni ścisłej, nie powinno być przeszkód dla zastosowania tego kryterium do sytuacji, w której projektowany obszar górniczy obejmuje kilka nieruchomości, w tym położonych na terytoriach sąsiadujących ze sobą województw.

Warto w tym miejscu zwrócić uwagę na niektóre problemy związane z ustaleniem przesłanek wyznaczających właściwość rzeczową starosty jako organu koncesyjnego. Dotyczy ona wyłącznie wydobywania kopalin ze złóż, jeżeli jednocześnie spełnione są wszystkie wymagania określone w art. 22 ust. 2. Wątpliwość może dotyczyć wielkości obszaru udokumentowanego złoża; nie może ona być większa niż 2 ha. Jeśli przekracza ona tę wartość, udzielenie takiej koncesji nie jest możliwe. Nie ma natomiast przeszkód, by w odrębnym postępowaniu dokonać podziału złoża poprzez wydzielenie z niego złoża o powierzchni nieprzekraczającej 2 ha.

Ustęp 3 komentowanego artykułu powinien znaleźć się w całkowicie innym miejscu. Nie dotyczy on właściwości starosty jako organu koncesyjnego, a wyłącznie terminu rozpoczęcia działalności prowadzonej na podstawie koncesji wspomnianego organu dotyczącej przyległego złoża. Zamiarem ustawodawcy była liberalizacja wymagań związanych $\mathrm{z}$ wykonywaniem działalności koncesjonowanej przez starostę. $Z$ dalszych przepisów wynika m.in., że elemen-

\footnotetext{
${ }^{1}$ Dz.U. 2019, poz. 2169 ze zm.
} 
tem wniosku o taką koncesję nie jest projekt zagospodarowania złoża (art. 27 ust. 3 zd. 2), przedsiębiorca nie sporządza planu zakładu górniczego (art. 105 ust. 2 pkt 1) ani dokumentacji mierniczo-geologicznej (art. 116 ust. 1), a nadto zwolniony jest z obowiązku tworzenia funduszu likwidacji zakładu górniczego (art. 128 ust. 13). W rezultacie koszty jego działalności są niższe, co powinno pobudzać przedsiębiorczość. Uzasadnienie projektu ustawy nie wyjaśnia jednak przyczyn wprowadzenia rozwiązania przewidzianego w art. 22 ust. 3 komentowanej ustawy. Można przypuszczać, że chodziło o uniknięcie sytuacji, w której przedsiębiorca prowadzący jednoczesne wydobycie w granicach przylegających do siebie obszarów górniczych utworzonych koncesjami starosty omijałby wymagania związane z koniecznością uzyskania koncesji marszałka województwa, konkurując ten sposób z przedsiębiorcami legitymującymi się koncesjami tego ostatniego organu. Nie jest natomiast dostatecznie jasne, czy ograniczenie przewidziane w art. 22 ust. 3 pr.g.g. miałoby znaleźć się w koncesji, czy też miałoby funkcjonować ex lege. Wypadałoby opowiedzieć się za tym drugim rozwiązaniem, aczkolwiek nie ma przeszkód, by informacja o treści korespondującej $\mathrm{z}$ omawianym art. 22 ust. 3 znalazła się w decyzji koncesyjnej.

W świetle art. 30 ust. 1 pkt 4 pr.g.g. obowiązkowym elementem koncesji jest wskazanie terminu rozpoczęcia określonej nią działalności, a w razie potrzeby określenie przesłanek, których spełnienie oznacza rozpoczęcie działalności. Powiązanie tego przepisu z art. 22 ust. 3 generuje trudności. Określenie „termin” musi bowiem nastąpić przez wskazanie daty bądź czasu upływającego od wskazanej (nawet pośrednio) daty (np. ostateczności decyzji koncesyjnej). Uchybienie terminowi rozpoczęcia działalności może natomiast skutkować cofnięciem koncesji (art. 37 ust. 1). W konsekwencji wyznaczenie terminu rozpoczęcia działalności uzależnionego od ostateczności decyzji stwierdzającej wygaśnięcie wcześniejszej koncesji może okazać się niewykonalne. Sprawa ulega dalszej komplikacji chociażby dlatego, że przedsiębiorca może uzyskać koncesję na wydobywanie kopaliny (z przylegających do siebie złóż) na terenie różnych powiatów, w dodatku w wyniku przeniesienia jej na inny podmiot (art. 36) bądź innych zdarzeń, o czym mogą nie mieć wiedzy pozostali starostowie. Warto jednocześnie zwrócić uwagę, że ograniczenie przewidziane w art. 22 ust. 3 pr.g.g. jest niezwykle proste do ominięcia, a ponadto jego respektowanie może kolidować z ustawowym nakazem racjonalnej gospodarki złożem (art. 125 pr.o.ś.). Rozwiązanie przewidziane w art. 22 ust. 3 pr.g.g. ma charakter wyjątkowy i w konsekwencji musi być interpretowane w sposób ścisły. Bezspornie nie dotyczy ono wydobywania z obszarów górniczych, które nie przylegają do siebie. Trafnie natomiast przyjmuje H. Schwarz, że określenie „ten sam rodzaj działalności" odnosi się do rodzaju kopaliny².

\footnotetext{
${ }^{2}$ H. Schwarz: Prawo geologiczne i górnicze. Komentarz. T. 1. Wrocław 2013, s. 192 i nast.
} 
Stosownie do art. 156 ust. 3 pr.g.g. określone ustawą zadania marszałków województw i starostów dotyczą spraw z zakresu administracji rządowej. Podobnie przewiduje art. 44 ust. 2 ustawy z dnia 6 marca 2016 r. - Prawo przedsiębiorców ${ }^{3}$, wedle którego ,jeżeli przepisy regulujące daną działalność gospodarczą stanowią, że wydawanie, odmowa wydania, zmiana zakresu i cofanie koncesji (...) należy do zadań organów jednostek samorządu terytorialnego, to zadania te są wykonywane jako zadania zlecone z zakresu administracji rządowej”. Organem wyższego stopnia w stosunku do działających jako organy koncesyjne:

- marszałków województw jest minister właściwy do spraw środowiska (art. 17 pkt $1 \mathrm{w}$ zw. z art. 157 pr.g.g.),

— starostów są samorządowe kolegia odwoławcze (art. 17 pkt 1 k.p.a.).

Art. 23.

1. Udzielenie koncesji na:

1) poszukiwanie lub rozpoznawanie rud pierwiastków promieniotwórczych oraz wydobywanie tych rud ze zlóż wymaga opinii Prezesa Państwowej Agencji Atomistyki;

1a) poszukiwanie i rozpoznawanie zlóż węglowodorów oraz wydobywanie węglowodorów ze złóż w granicach obszarów morskich Rzeczypospolitej Polskiej albo wydobywanie węglowodorów ze złóż w granicach obszarów morskich Rzeczypospolitej Polskiej wymaga opinii Prezesa Wyższego Urzędu Górniczego w zakresie technicznych możliwości wykonywania działalności oraz zapewnienia jej bezpieczeństwa;

1b) poszukiwanie i rozpoznawanie zlóż węglowodorów oraz wydobywanie węglowodorów ze złóż w granicach obszarów morskich Rzeczypospolitej Polskiej albo wydobywanie węglowodorów ze zlóż w granicach obszarów morskich Rzeczypospolitej Polskiej wymaga opinii Ministra Obrony Narodowej i ministra wlaściwego do spraw rybolówstwa, w zakresie lokalizacji obszaru prowadzenia zamierzonej działalności;

2) wydobywanie $z$ gruntów pod wodami śródlądowymi oraz $z$ obszarów, o których mowa $w$ art. 169 ust. 2 ustawy $\mathrm{z}$ dnia 20 lipca $2017 \mathrm{r}$. - Prawo wodne (Dz. U. z 2018 r. poz. 2268 oraz z 2019 r. poz. 125 i 534) ${ }^{4}$, wymaga uzgodnienia $z$ organem odpowiedzialnym za utrzymanie wód oraz opinii organu właściwego do wydania pozwolenia wodnoprawnego;

${ }^{3}$ Dz.U. 2019, poz. 1292 ze zm.

${ }^{4}$ Obecnie Dz.U. 2020, poz. 310 ze zm. 
3) wydobywanie kopalin, o których mowa w art. 10 ust. 1, ze zlóż, podziemne bezzbiornikowe magazynowanie substancji oraz podziemne składowanie dwutlenku węgla wymaga uzgodnienia z ministrem właściwym do spraw gospodarki złożami kopalin;

4) podziemne składowanie dwutlenku węgla wymaga uzyskania opinii Komisji Europejskiej.

1a. Udzielenie koncesji na poszukiwanie i rozpoznawanie złóż węglowodorów oraz wydobywanie węglowodorów ze zlóż, a także wydanie decyzji inwestycyjnej, o której mowa $\mathrm{w}$ art. $49 \mathrm{z}$ ust. 1 , wymaga uzgodnienia $\mathrm{z}$ ministrem właściwym do spraw gospodarki złożami kopalin.

2. W odniesieniu do działalności prowadzonej poza granicami obszarów morskich Rzeczypospolitej Polskiej udzielenie koncesji na:

1) poszukiwanie lub rozpoznawanie złóż kopalin, z wyłączeniem złóż węglowodorów, albo poszukiwanie lub rozpoznawanie kompleksu podziemnego składowania dwutlenku węgla,

2) poszukiwanie i rozpoznawanie złóż węglowodorów oraz wydobywanie węglowodorów ze zlóż

- wymaga opinii wójta (burmistrza, prezydenta miasta) wlaściwego ze względu na miejsce wykonywania zamierzonej działalności.

2a. W odniesieniu do działalności prowadzonej poza granicami obszarów morskich Rzeczypospolitej Polskiej:

1) udzielenie koncesji na wydobywanie kopalin ze złóż, podziemne bezzbiornikowe magazynowanie substancji, podziemne składowanie odpadów albo podziemne składowanie dwutlenku węgla,

2) wydanie decyzji inwestycyjnej, o której mowa w art. 49z ust. 1

- wymaga uzgodnienia z wójtem (burmistrzem, prezydentem miasta) właściwym ze względu na miejsce wykonywania zamierzonej dzialalności; kryterium uzgodnienia jest nienaruszanie zamierzoną dzialalnością przeznaczenia lub sposobu korzystania $\mathrm{z}$ nieruchomości określonego w sposób przewidziany $w$ art. 7 .

3. Udzielenie koncesji przez starostę wymaga opinii marszalka województwa.

4. W przypadku, o którym mowa w ust. 1 pkt 4, organ koncesyjny przesyla do Komisji Europejskiej kopię wniosku o udzielenie koncesji na podziemne składowanie dwutlenku węgla wraz z załącznikami oraz projekt decyzji, w terminie miesiąca od dnia otrzymania wniosku.

5. W przypadku, o którym mowa w ust. 1 pkt 4, organ koncesyjny wydaje decyzję:

1) po otrzymaniu opinii Komisji Europejskiej albo

2) po otrzymaniu od Komisji Europejskiej informacji o rezygnacji z wydawania opinii. 
Koncesja na działalność regulowaną komentowaną ustawą nigdy nie jest samodzielnym rozstrzygnięciem organu koncesyjnego i zawsze wymaga współdziałania z co najmniej jednym tzw. organem współdziałającym (zależnie od szczegółów - uzgadniającym bądź opiniującym, zob. wyrok ${ }^{5}$ WSA z dnia 2 marca 2005 r., VI SA/Wa 872/04). Warto w tym miejscu wspomnieć, że wyliczenie przewidziane $\mathrm{w}$ art. 23 pr.g.g. jest niepełne, dodatkową regulację przewiduje bowiem art. 8 , wedle którego decyzje podejmowane na podstawie omawianej ustawy dotyczące:

- morskich wód wewnętrznych RP, morza terytorialnego RP oraz tzw. pasa nadbrzeżnego - wymagają uzgodnienia $\mathrm{z}$ dyrektorem właściwego urzędu morskiego,

— wyłącznej strefy ekonomicznej RP — wymagają uzgodnienia z ministrem właściwym do spraw gospodarki morskiej.

Określenie „udzielenie koncesji (...) wymaga” oznacza, że podjęcie decyzji odmownej co do zasady nie musi być poprzedzone omawianym współdziałaniem (zob. wyrok NSA z dnia 27 listopada 2018 r., II GSK 3899/16). Inaczej mówiąc, wspomniane współdziałanie jest przesłanką decyzji o udzieleniu koncesji, a nie odmownej.

O dalszych szczegółach współdziałania w postępowaniu koncesyjnym rozstrzyga art. 23 pr.g.g. $Z$ procesowego punktu widzenia problem wygląda następująco:

- $\mathrm{z}$ wnioskiem o zajęcie stanowiska może wystąpić wyłącznie organ koncesyjny po wszczęciu postępowania, zawiadamiając o tym strony postępowania (art. $106 \S 2$ k.p.a.). Niedopuszczalne jest (niekiedy praktykowane) uzyskiwanie stanowiska organu współdziałającego przez wnioskodawcę. Ustawa nie rozstrzyga, na jakim etapie postępowania należy zasięgnąć stanowiska organu współdziałającego. Sformułowanie „udzielenie koncesji (...) wymaga (...)" przesądza jednak, że skoro organ współdziałający wypowiada się $\mathrm{w}$ przedmiocie udzielenia koncesji, to elementem wystąpienia o zajęcie stanowiska powinien być projekt decyzji w sprawie jej udzielenia. Inaczej mówiąc wspomniane współdziałanie byłoby finalnym etapem postępowania wyjaśniającego. Warto w tym miejscu zwrócić uwagę na błędną praktykę polegającą na tym, że do wystąpienia o uzgodnienie bądź opinię dołącza się wyłącznie wniosek koncesyjny (a nie projekt koncesji),

- organ współdziałający zajmuje stanowisko w terminie 14 dni, pod rygorem domniemania zgody; uważa się że termin ten jest zachowany, jeżeli organ współdziałający przed jego upływem doręczył postanowienie w tej sprawie lub dokonał jego wysyłki (art. 9 pr.g.g.). Termin ten nie może zostać przedłużony. Wspomniany przepis ma bowiem charakter szczególny w stosunku do wymagań kodeksu postępowania administracyjnego do-

${ }^{5}$ Wszystkie powołane wyroki wojewódzkich sądów administracyjnych są prawomocne. 
tyczących skutków uchybienia wymaganiom dotyczącym terminów załatwiania spraw,

- formą wyrażenia stanowiska organu współdziałającego jest postanowienie podjęte (w razie potrzeby) po przeprowadzeniu niezbędnego postępowania wyjaśniającego; podlega ono kontroli instancyjnej i sądowoadministracyjnej (art. $106 \S 4-5$ k.p.a.).

Sporną kwestią może natomiast być odpowiedź na pytanie, czy niezbędną przesłanką koncesji jest tylko ostateczne postanowienie organu współdziałającego, czy też — skoro w świetle art. 143 k.p.a. wniesienie zażalenia nie wstrzymuje wykonania postanowienia - brak cechy ostateczności nie stanowi przeszkody do uzyskania koncesji. Zdaniem NSA wydanie decyzji przed rozpoznaniem zażalenia $\mathrm{w}$ przedmiocie zajęcia stanowiska, o którym mowa w art. $106 \S 5$ k.p.a., narusza art. $106 \S 1$ k.p.a. (uchwała 7 Sędziów z dnia 9 listopada 1998 r., OPS 8/98). Inaczej mówiąc, zdaniem NSA oparcie koncesji na nieostatecznym postanowieniu w przedmiocie jej uzgodnienia narusza prawo. Ocena ta w pełni koresponduje z funkcją wspomnianego „uzgodnienia” rozumianego jako uzależnienie koncesji od zgody innego organu. W najnowszym komentarzu do art. 106 k.p.a. (B. Adamiak, J. Borkowski, Kodeks postępowania administracyjnego. Komentarz. Wyd. 16, Legalis/el 2019) stanowisko wypowiedziane we wspomnianej uchwale oceniono jako „doniosły procesowo pogląd". Odmiennie przyjmują Cz. Martysz (Komentarz do art. 106 Kodeksu postępowania administracyjnego. LEX/el 2010, teza 11) oraz G. Łaszczyca (Komentarz do Kodeksu postepowania administracyjnego. LEX/el 2010, teza 2).

Organ koncesyjny nie jest natomiast stroną postępowania (ani podmiotem na prawach strony) w przedmiocie takiego współdziałania, a zwłaszcza nie może inicjować postępowań zmierzających do wyeliminowania tych postanowień podjętych $\mathrm{w}$ ramach współdziałania, które $\mathrm{w}$ jego ocenie są niezgodne $\mathrm{z}$ prawem. Gdyby natomiast stroną postępowania koncesyjnego byłaby gmina (np. z tytułu prawa własności nieruchomości objętej projektowanym obszarem górniczym), jej organ wykonawczy podlegałby wyłączeniu w omawianym współdziałaniu (art. 24 k.p.a.).

Nie można wykluczyć, że organ koncesyjny będzie jednocześnie organem, współdecydującym, co można dostrzec na przykładzie prezydenta miasta na prawach powiatu. Jest on organem o poszerzonych kompetencjach, przysługujących zarówno staroście, jak i organowi wykonawczemu gminy. W konsekwencji obowiązek współdziałania przewidzianego w art. 23 ust. 2-2a staje się wówczas bezprzedmiotowy (zob. wyroki NSA: z dnia 25 maja 2005 r., OSK 1660/04; z dnia 4 października 2007 nr., II OSK 997/07; z dnia 16 października 2007 r., II OSK 1401/06) ${ }^{6}$. Nie zwalnia to jednak takiego organu koncesyjnego od prze-

${ }^{6}$ Co prawda przedmiotem tych wyroków nie były sprawy regulowane komentowaną ustawą, jednak stan prawny stanowiący podstawę ich wydania oparty był takich samych schematach. 
prowadzenia postępowania wyjaśniającego w zakresie przesłanek przewidzianych w art. 7 pr.g.g. oraz udokumentowania jego wyników w aktach sprawy.

Zakres oraz sposób wspomnianego współdziałania zależą od rodzaju zamierzonej działalności i miejsca jej wykonywania. Szczegóły zasługują niestety na ocenę krytyczną, a praktyka ich stosowania $\mathrm{z}$ wielu przyczyn niekiedy przybiera charakter wręcz patologiczny, czego dowodem jest treść stanowisk niektórych organów współdziałających. Nie do rzadkości należą sytuacje, w których pomimo wystąpienia o „uzgodnienie” organ współdziałający przedstawia tylko „opinię" (bądź odwrotnie), nadaje swemu stanowisku formę zwykłego pisma (a nie postanowienia zawierającego uzasadnienie i pouczenie o terminie oraz trybie zaskarżenia), uzgadnia „warunkowo” (w tym żądając spełnienia wymagań, które wynikają z powszechnie obowiązujących przepisów czy też są całkowicie niezgodne z prawem), zawiadamia, że nie zajmie stanowiska lub też kieruje się przesłankami całkowicie pozaprawnymi.

Problem ustalenia organów administracji właściwych w zakresie takiego współdziałania nie budzi większych wątpliwości. Zostały one bowiem (czasami pośrednio) wskazane przez ustawę. Niektóre problemy wymagają jednak rozwinięcia. Dotyczy to zwłaszcza prawa wodnego. W jego rozumieniu „gruntami pokrytymi wodami” są ,grunty tworzące dna i brzegi cieków wodnych, jezior oraz innych naturalnych zbiorników wodnych w granicach linii brzegu, a także grunty wchodzące w skład sztucznych zbiorników wodnych, stopni wodnych oraz jezior podpiętrzonych, będące gruntami pokrytymi wodami powierzchniowymi przed wykonaniem urządzeń piętrzących" (art. 10 pkt 16). Wedle art. 169 ust. 2 tej ustawy „na mapach zagrożenia powodziowego przedstawia się w szczególności: 1) obszary, na których prawdopodobieństwo wystąpienia powodzi jest niskie i wynosi $0,2 \%$ lub na których istnieje prawdopodobieństwo wystąpienia zdarzenia ekstremalnego ; 2) obszary szczególnego zagrożenia powodzią obejmujące tereny narażone na zalanie w przypadku uszkodzenia lub zniszczenia: a) wału przeciwpowodziowego, b) wału przeciwsztormowego, c) budowli piętrzącej". Powstaje natomiast pytanie, czy użyte w art. 23 ust. 1 pkt 2 pr.g.g. określenie „obszarów, o których mowa w art. 169 ust. 2" pr.wodn. oznacza, że chodzi tylko o takie obszary w ten sposób określone na mapach zagrożenia powodziowego zatwierdzonych przez ministra właściwego do spraw środowiska

\footnotetext{
${ }^{7}$ Pojęcie to nie doczekało się definicji ustawowej.
}

${ }^{8}$ Wedle art. 16 pkt 34 obszarami szczególnego zagrożenia powodzią są: a) obszary, na których prawdopodobieństwo wystąpienia powodzi jest średnie i wynosi $1 \%$, b) obszary, na których prawdopodobieństwo wystąpienia powodzi jest wysokie i wynosi $10 \%$, c) obszary między linią brzegu a wałem przeciwpowodziowym lub naturalnym wysokim brzegiem, w który wbudowano wał przeciwpowodziowy, a także wyspy i przymuliska powstałe w sposób naturalny na gruntach pokrytych wodami powierzchniowymi, stanowiące działki ewidencyjne, d) pas techniczny (w rozumieniu ustawy z dnia 21 marca 1991 r. o obszarach morskich Rzeczypospolitej Polskiej i administracji morskiej). 
i umieszczonych na stronie podmiotowej Biuletynu Informacji Publicznej obsługującego urząd tegoż organu administracji (art. 171 pr.wodn.), czy też istnienie wspomnianych map nie ma znaczenia. Potrzeba pewności prawa przemawia za pierwszym z tych rozwiązań. W praktyce ustalenie szczegółów może natomiast nastręczać sporo trudności. Środkiem pozwalającym na ich przezwyciężenie może być współdziałanie organów koncesyjnych z organami właściwymi w zakresie gospodarki wodnej, „w zakresie niezbędnym do dokładnego wyjaśnienia stanu faktycznego i prawnego sprawy, mając na względzie interes społeczny i słuszny interes obywateli oraz sprawność postępowania, przy pomocy środków adekwatnych do charakteru, okoliczności i stopnia złożoności sprawy" (art. $7 \mathrm{~b}$ k.p.a.). Istota takiego współdziałania polega na uzyskaniu informacji od innego (w danej sprawie - właściwego w zakresie gospodarki wodnej) organu bądź zasięgnięciu jego opinii. Jego stanowisko przybiera postać zwykłego pisma, niepodlegającego rygorom art. 106 k.p.a., a przede wszystkim nie ma charakteru wiążącego. W istocie stanowi ono środek pozwalający na wszechstronne wyjaśnienie wszystkich istotnych okoliczności sprawy (art. 7 i 77 k.p.a.). Utrzymywanie wód jest obowiązkiem ich właścicieli (art. 226, art. 231 pr.wodn.). Nakaz „uzgodnienia z organem odpowiedzialnym za utrzymanie wód” ma rację bytu tylko wówczas, gdy jest nim właściwy organ Wód Polskich (zob. art. 240 ust. 4 pkt 8 pr.wodn.). Organy Wód Polskich są właściwe również w odniesieniu do pozwoleń wodnoprawnych (art. 397 pr.wodn.).

Różnica pomiędzy „opinią” oraz „uzgodnieniem” polega na tym, że to ostatnie $\mathrm{w}$ istocie jest wyrazem zgody organu uzgadniającego. Inaczej mówiąc, nakaz „,uzgodnienia koncesji” oznacza, że organ koncesyjny może ją udzielić tylko za zgodą (niekiedy domniemaną, zob. art. 9 pr.g.g.) organu uzgadniającego. Odmowa uzgodnienia, czasami błędnie nazywana „uzgodnieniem negatywnym”, wyklucza wydanie koncesji (wyrok WSA z dnia 9 czerwca 2006 r., VI SA/Wa 839/06). Zwrot „wymaga uzgodnienia” wyklucza też możliwość „uzgodnienia warunkowego" (odmiennie, jak się wydaje nietrafnie, przyjęto w wyroku WSA z dnia 24 kwietnia 2007 r., VI SA/Wa 178/07). Czym innym jest natomiast „opinia” organu współdziałającego. W istocie stanowi ona wyraz niewiążącego stanowiska takiego organu. Nie ma zatem przeszkód do podjęcia decyzji koncesyjnej niezgodnej z opinią organu współdziałającego.

Znacznie trudniej jest natomiast odpowiedzieć na pytanie, czym powinien kierować się organ współdziałający (opiniujący, uzgadniający). Przede wszystkim dyrektywy wynikające $z$ art. 7 Konstytucji oraz 6 k.p.a. wykluczają (niestety w praktyce nierzadką) dowolność w określaniu przesłanek, jakimi winien kierować się organ współdziałający. Ustawodawca nie wykazał natomiast zainteresowania ich doprecyzowaniem. Powstaje również wątpliwość, czy zakres wspomnianego współdziałania nie został określony zbyt szeroko.

Jedna z kluczowych wskazówek w tej mierze zdaje się wynikać z art. 7 pr.g.g., wedle którego podejmowanie i wykonywanie działalności określonej ustawą jest 
dozwolone tylko wówczas, jeżeli nie naruszy ona przeznaczenia nieruchomości określonego $\mathrm{w}$ miejscowym planie zagospodarowania przestrzennego oraz w odrębnych przepisach (ust. 1). W przypadku braku miejscowego planu zagospodarowania przestrzennego podejmowanie i wykonywanie działalności określonej ustawą jest dopuszczalne tylko wówczas, jeżeli nie naruszy ona sposobu wykorzystywania nieruchomości ustalonego w studium uwarunkowań i kierunków zagospodarowania przestrzennego gminy ${ }^{9}$ oraz w odrębnych przepisach (ust. 2). Co do szczegółów zob. komentarz do art. 7 pr.g.g.

Warto również zwrócić uwagę, że przesłanki określone w art. 7 pr.g.g. różnią się od przewidzianych dotychczasowym stanem prawnym. Pod rządem art. 16 ust. 5 pr.g.g. $1994^{10}$ (a przynajmniej w końcowym okresie jego obowiązywania) podstawą uzgodnienia koncesji dokonywanego z organem wykonawczym gminy był miejscowy plan zagospodarowania przestrzennego, a w razie jego braku - wspomniane studium. Zakładano, że do uzgodnienia może dojść tylko w razie zgodności zamierzonej działalności ze wspomnianymi dokumentami. Oparte na tym stanie prawnym orzecznictwo sądów administracyjnych wypracowało pogląd, że jako jedyne kryterium uzgodnienia udzielenia koncesji na działalność polegającą na wydobywaniu kopalin ze złóż czyni ona zgodność zamierzenia koncesyjnego z ustaleniami miejscowego planu zagospodarowania przestrzennego, jeżeli jest uchwalony, lub z ustaleniami studium. Przewidziane kryteria należy stosować w sposób ścisły. Niedopuszczalne jest stosowanie innych kryteriów, niż te, które są przewidziane w ustawie, w szczególności odpowiedniego stosowania przepisów ustawy o planowaniu i zagospodarowaniu przestrzennym. Prawo geologiczne i górnicze jest jedynym aktem normatywnym regulującym zasady wykonywania określonej tam działalności (wyroki: NSA z dnia 7 października 2010 r., II GSK 703/10; WSA z dnia 27 lutego 2008 r., II SA/Rz 865/07). Co do zasady ${ }^{11}$ oceny te nadal zachowują aktualność. Postanowienie o odmowie uzgodnienia koncesji, które nie odnosi się do treści planu miejscowego, a w razie jego braku do studium, narusza prawo i nie może funkcjonować w obrocie prawnym (wyrok WSA z dnia 30 sierpnia 2013 r., II SA/Rz 486/13).

Stosownie do art. 23 ust. 2 pkt 2a pr.g.g. kryterium uzgodnienia koncesji (na wydobywanie kopalin ze złóż, podziemne bezzbiornikowe magazynowanie substancji, podziemne składowanie odpadów, podziemne składowania dwutlenku węgla) czy też wydanie tzw. decyzji inwestycyjnej (art. 49z

${ }^{9}$ Dalej powoływane jako „studium”.

${ }^{10}$ Ustawa z dnia 4 lutego 1994 r. - Prawo geologiczne i górnicze, Dz.U. 2005, nr 228, poz. 1947 ze zm.

${ }^{11} \mathrm{Z}$ zastrzeżeniem, że obecnie ustawa nie wymaga „zgodności” zamierzonej działalności ze wspomnianymi dokumentami planistycznymi. Wystarczy, by zamierzona działalność nie naruszała określonego nimi przeznaczenia bądź (w razie braku planu miejscowego) sposobu wykorzystywania nieruchomości. 
ust. 1 pr.g.g.) dokonywane z organem wykonawczym gminy ma być nienaruszanie zamierzoną działalnością „,przeznaczenia lub sposobu korzystania z nieruchomości określonego w sposób przewidziany w art. 7". Inaczej mówiąc, oznacza to, że przesłanki wspomnianego uzgodnienia określa art. 7 pr.g.g. Szczegóły zależą natomiast od rodzaju zamierzonej działalności oraz miejsca jej wykonywania. O ile ma ona odbywać się w granicach przestrzennych nieruchomości gruntowej pojmowanej jako powierzchniowa warstwa skorupy ziemskiej (art. $46 \mathrm{w}$ zw. z art. 143 k.c.), wówczas przesłanką uzgodnienia (a w istocie podjęcia decyzji koncesyjnej) będzie odpowiedź na pytanie, czy zamierzona działalność narusza ustalone planem miejscowym przeznaczenie bądź (jeżeli nie ma planu miejscowego), ustalony przez studium sposób wykorzystywania nieruchomości gruntowej. Jeżeli np. przedmiotem koncesji miałoby być wydobywanie kopaliny metodą odkrywkową, do uzgodnienia mogłoby dojść tylko wówczas, gdyby zamierzona działalność nie naruszała ustalonego przeznaczenia bądź sposobu wykorzystywania nieruchomości. Jest bowiem oczywiste, że odkrywkowe wydobywanie kopalin w zasadzie wyklucza inne sposoby wykorzystywania objętych nim nieruchomości. Inaczej problem ten może wyglądać $\mathrm{w}$ odniesieniu do działalności prowadzonej poza granicami przestrzennymi nieruchomości (podziemne wydobywanie kopalin, podziemne magazynowanie bądź składowanie itd.). Istnieje wówczas możliwość pogodzenia przeznaczenia nieruchomości (bądź sposobu wykorzystywania jej) z wydobywaniem kopalin. Inaczej mówiąc, rolne, leśne, budowlane (itd.) przeznaczenie nieruchomości bądź wspomniany sposób wykorzystywania jej nie mogą stanowić przesłanki negatywnego stanowiska organu współdziałającego (zwłaszcza uzgadniającego) w przypadku działalności wykonywanej poza granicami przestrzennymi nieruchomości (jak np. w razie wydobywania kopalin metodą podziemną).

Stanowisko organu wykonawczego gminy uzgadniającego koncesję przede wszystkim determinowane jest przez miejscowy plan zagospodarowania przestrzennego (będący aktem prawa miejscowego) bądź „odrębne przepisy”. Tymi ostatnimi będą ustawy lub podjęte na ich podstawie rozstrzygnięcia o charakterze generalnym, które bezpośrednio określają przeznaczenie nieruchomości lub dozwolony (zabroniony) sposób ich wykorzystywania. Przykładami może być (bezpośrednio przewidziany przepisem prawa) reżim ochronny gruntów rolnych i leśnych ${ }^{12}$, stanowiący konsekwencję ustanowienia niektórych obszarowych form ochrony przyrody, obowiązujący w obrębie niektórych form ochrony wód itd. Zdaniem WSA przepisami odrębnymi w rozumieniu art. 7 pr.g.g. nie są indywidualne akty administracyjne (wyrok z dnia 27 grudnia 2013 r., III SA/ Lu 612/13). Sprawę komplikują natomiast liczne ustawy określające „szczególne

${ }^{12}$ Ustawa z dnia 3 lutego 1995 r. o ochronie gruntów rolnych i leśnych. Dz.U. 2017, poz. 1161. 
zasady" realizacji niektórych przedsięwzięćc ${ }^{13}$. Podejmowane na ich podstawie decyzje, określając przeznaczenie terenu (w istocie nieruchomości gruntowych) w sposób pozwalający na realizację objętych nimi przedsięwzięć, zapadają z wyłączeniem systemu planowania i zagospodarowania przestrzennego.

Problem również w tym, że sporządzenie miejscowego planu zagospodarowania przestrzennego nie ma charakteru obowiązkowego. O ile takowego planu nie sporządzono, przesłanką uzgodnienia koncesji ma być sposób wykorzystywania nieruchomości ustalony przez studium oraz odrębne przepisy (art. 7 pr.g.g.). W istocie wymagania te wyznaczają przesłanki, jakimi winny kierować się organy wykonawcze gmin uczestniczące w procedurach koncesyjnych.

Rozwiązanie zakładające, że przesłankę uzgodnienia (opinii) stanowi przede wszystkim miejscowy plan zagospodarowania przestrzennego, systemowo koresponduje z prawnym charakterem tego ostatniego; bezspornie jest on aktem prawa miejscowego. Podobnie problem ten należy postrzegać w odniesieniu do „przepisów odrębnych”. Strukturalnie wadliwa (a nawet szkodliwa) jest natomiast konstrukcja zakładająca, że w razie braku planu miejscowego oraz ,przepisów odrębnych" uzgodnienie (przedstawienie opinii) następuje na podstawie kryterium „sposobu wykorzystywania nieruchomości ustalonego w studium”. To ostatnie bezspornie nie ma charakteru normatywnego, a w dodatku nie podlega promulgacji. Problem również w tym, że nierzadko plany miejscowe oraz studia ignorują ustawowe wymagania związane z gospodarką złożami kopalin (zob. art. 72 pr.o.ś., art. 98 pr.g.g.), z oczywistą szkodą dla interesu publicznego.

Rozstrzygnięcie w przedmiocie omawianego uzgodnienia lub opinii wymaga dokonania wykładni przede wszystkim planu miejscowego, a w razie jego braku — studium. Nieporozumieniem jest jednak ocena, że „organy gminy są najbardziej właściwe w zakresie wykładni ich przepisów"14, czyli zawartych w planach miejscowych i zapewne w studiach (chociaż te ostatnie nie mają charakteru normatywnego). Wykładni prawa miejscowego dokonuje ten, kto je stosuje, w tym np. samorządowe kolegium odwoławcze, starosta (np. orzekając w przedmiocie pozwolenia na budowę), sądy (administracyjne, powszechne) oraz inne organy. Podobnie należy przyjąć w odniesieniu do wykładni studium.

13 Jak np. ustawy:

- z dnia 10 kwietnia 2003 r. o szczególnych zasadach przygotowania i realizacji inwestycji w zakresie dróg krajowych. Dz.U. 2018, poz. 1474 ze zm.,

- z dnia 24 lipca 2015 r. o przygotowaniu i realizacji strategicznych inwestycji w zakresie sieci przesyłowych. Dz.U. 2020, poz. 191 ze zm.,

- z dnia 24 lutego 2017 r. o inwestycjach w zakresie budowy drogi wodnej łączącej Zalew Wiślany z Zatoką Gdańską. Dz.U. 2019, poz. 1073 ze zm.,

- z dnia 22 lutego 2019 r. o przygotowaniu i realizacji strategicznych inwestycji w sektorze naftowym. Dz.U. 2019, poz. 630 ze zm.

14 Zob. J. MurzydŁo: Znaczenie miejscowego planu zagospodarowania przestrzennego $w$ świetle zmian wprowadzonych art. 7 ustawy z 9.06.2011 r. - Prawo geologiczne i górnicze. „Finanse Komunalne” 2013, nr 3, s. 54. 
Problem jednak w tym, że wiele wspomnianych dokumentów planistycznych operuje wyjątkowo nieprecyzyjną terminologią, zawiera wewnętrzne sprzeczności i nie spełnia wymagań ustawowych ${ }^{15}$.

Nawet czasowa utrata pierwotnego charakteru gruntu musi być kwalifikowania jako działalność sprzeczna ze studium, zwłaszcza jeżeli na danym obszarze dojdzie do zmiany warunków wodno-glebowych, gdyż na terenie objętym inwestycją powstanie zbiornik wodny, którego do tej pory nie było i którego nie przewiduje studium (wyrok WSA z dnia 10 lutego 2010 r., II SA/Bd 56/10). Trafnie przyjęto też, że zasadność rozwiązań planu miejscowego nie może być przedmiotem oceny w postępowaniu prowadzonym przez organy administracji w sprawie uzgodnienia koncesji na wydobywanie kopaliny. W ramach niniejszego postępowania nie może być dokonana ocena prawidłowości postępowania organów gminy w ramach procedury uchwalania miejscowego planu zagospodarowania przestrzennego (wyrok WSA z dnia 5 maja 2010 r., III SA/Łd 100/10). Oceny te wypowiedziano wprawdzie pod rządem poprzedniego stanu prawnego, jednak nadal zachowują swą aktualność.

Brak podstaw do uzgodnienia koncesji na wydobywanie kopaliny ze złoża znajdującego się w strefie gospodarki rolnej na gruntach o wysokiej jakości produkcyjnej, które są chronione przed zmianą użytkowania (wyrok WSA z dnia 4 grudnia 2013 r., III SA/Kr 286/13). Jeżeli ze studium wynika, że złoże kopaliny położone jest na obszarze rolniczej przestrzeni produkcyjnej przeznaczonym do rozwoju intensywnego rolnictwa, uzgodnienie koncesji na wydobywanie kopaliny nie jest możliwe (wyrok NSA z dnia 21 września 2018 r., II GSK 515/18).

Praktyka nie zawsze dostrzega zmiany stanu prawnego zaistniałe w wyniku wejścia w życie komentowanej ustawy z dnia 9 czerwca 2011 r. Przykładem może być wyrok WSA z dnia 11 marca 2014 r. (II SA/Bd 1590/13) ${ }^{16}$. Przyjęto w nim, że jako jedyne kryterium uzgodnienia udzielenia koncesji na działalność polegającą na wydobywaniu kopalin ze złóż pr.g.g. 1994 czyni zgodność zamierzenia koncesyjnego z ustaleniami miejscowego planu zagospodarowania przestrzennego (jeżeli został uchwalony) lub z ustaleniami studium. Pogląd ten zachowuje aktualność na gruncie ustawy z 2011 r., pomimo różnic redakcyjnych przepisu art. 23 ust. 2 pkt 2 pr.g.g. poprzednio obowiązującej ustawy i art. 7 ust. $2^{17}$ ich treść jest bowiem zbliżona. Postępowanie w przedmiocie uzgodnienia koncesji $\mathrm{w}$ trybie art. 23 ust. $2 \mathrm{a}$ pkt $1 \mathrm{w}$ związku z art. 7 ust. 1 i ust. 2 pr.g.g. ogranicza się do badania zgodności działalności objętej projektem koncesji z miejscowym planem zagospodarowania przestrzennego. Działalność

${ }^{15}$ Zob. A. LiPIŃSKI: Miejscowy plan zagospodarowania przestrzennego jako źródto prawa. „Prawne Problemy Górnictwa i Ochrony Środowiska” 2017, nr 1, s. 34 i nast.

16 Podobnie przyjęto w wyroku WSA z dnia 4 grudnia 2013 r., III SA/Kr 286/13.

${ }_{17}$ Przywołanie art. 23 ust. 2 pkt 2 jako przepisu „poprzednio obowiązującej ustawy” (czyli pr.g.g. 1994) jest oczywistym błędem, bezspornie bowiem jest to przepis aktualnie obowiązujący. Pod rządem pr.g.g. 1994 przesłanki wspomnianego uzgodnienia określał art. 16 ust. 5. 
niespełniająca powyższego kryterium nie będzie mogła być uzgodniona. Podobne stanowisko zajął WSA w wyroku z dnia 2 października 2014 r. (II SA/Ol 845/14), przyjmując, że w razie braku planu miejscowego kluczowym kryterium uzgodnienia udzielenia koncesji na wydobywanie kopalin jest zgodność zamierzenia koncesyjnego z ustaleniami studium, co wymaga analizy porównawczej. W wyroku z dnia 30 sierpnia 2017 r. (III SA/Gl 599/17) WSA przyjął, że przewidziane w planie zagospodarowania przestrzennego kryteria należy stosować w sposób ścisły. Przedstawione wyżej oceny tylko częściowo są trafne, co najłatwiej dostrzec, porównując dotychczasowy i obecny stan prawny.

Zdaniem NSA ,uprawnienie organu gminy do uzgodnienia udzielenia koncesji na wydobycie kopalin (art. 23 ust. 2a pr.g.g.) w zakresie stwierdzenia nienaruszalności przez eksploatację przeznaczenia nieruchomości określonego w miejscowym planie zagospodarowania przestrzennego (art. 7 pr.g.g.) nie daje podstaw do określania wymogów eksploatacji złoża w planie miejscowym. To organ koncesyjny, a nie gmina, ma zbadać w oparciu o art. 7 ust. 1 pr.g.g., czy warunki eksploatacji złoża będą zgodne z planem miejscowym i udzielić lub odmówić koncesji. Organ gminy dokonuje oceny zgodności warunków planowanej eksploatacji z planem, ale nie wyznacza wymogów dla takiej eksploatacji” (wyrok z dnia 1 marca 2017 r., II OSK 2832/16).

W niektórych sytuacjach (art. 23 ust. 2) niezbędną przesłankę uzyskania koncesji stanowi opinia organu wykonawczego gminy. Skoro podjęcie działalności wymaga koncesji (np. na poszukiwanie lub rozpoznawanie złóż kopalin wymienionych $\mathrm{w}$ art. 10 ust. 1), to w konsekwencji wspomniany organ również powinien kierować się kryteriami wynikającymi z art. 7 pr.g.g. Co prawda wspomniany art. 23 ust. 2 nie odsyła do art. 7 komentowanej ustawy, niemniej jednak przedstawiony wyżej wniosek znajduje swe uzasadnienie w wykładni funkcjonalnej. W konsekwencji oceny w przedmiocie przesłanek wspomnianej opinii, wypowiadane pod rządem dotychczasowego stanu prawnego, utraciły swą aktualność. Przykładem może być wyrok WSA z dnia 15 czerwca 2007 r. (VI SA 1509/06) gdzie przyjęto, że skoro w przedmiocie wniosku o udzielenie koncesji na poszukiwanie i rozpoznanie złoża ustawodawca daje możliwość organowi opiniującemu wyrażenia tejże opinii bez konkretnych ustawowych wymogów, jakimi ma się kierować, oznacza to, że kierunek ten w szczególności wytyczają zadania ustawowe organu opiniującego w zakresie praw i obowiązków w sprawach istotnych dla społeczności lokalnej.

Brak natomiast wyraźnej odpowiedzi na pytanie, czym powinny kierować się pozostałe organy współdziałające, jak np. minister właściwy do spraw gospodarki złożami kopalin, do zadań którego należy uzgadnianie koncesji na wydobywanie większości kopalin objętych własnością górniczą oraz na podziemne bezzbiornikowe magazynowanie substancji (art. 23 ust. 1 pkt 2 pr.g.g.). W obecnym stanie prawnym dział administracji rządowej ,gospodarka złożami kopalin" obejmuje sprawy: 
1) prowadzenia, w porozumieniu z ministrem właściwym do spraw środowiska, racjonalnej gospodarki złożami węglowodorów, węgla brunatnego, węgla kamiennego, siarki rodzimej, soli kamiennej, soli potasowej, soli potasowo-magnezowej, w obszarze objętym wydobyciem,

2) uzgadniania koncesji na wydobywanie udzielanych przez ministra właściwego do spraw środowiska w zakresie kopalin objętych własnością górniczą Skarbu Państwa,

3) współpracy w nadzorze nad wydobywaniem kopalin, o których mowa w pkt 1,

4) kwalifikacji w zakresie górnictwa (art. 11a ustawy z dnia 4 września 1997 r. o działach administracji rządowej $^{18}$ ).

Zadania te wykonuje Minister Aktywów Państwowych (rozporządzenie Prezesa Rady Ministrów z dnia 18 listopada 2019 r. $)^{19}$. Analiza spraw objętych wspomnianym działem nie daje jednak odpowiedzi, jakimi przesłankami należy kierować się, dokonując wspomnianego uzgodnienia. Można wprawdzie bronić zapatrywania, że przesłanką uzgodnienia ma być zgodność zamierzonej koncesji z zasadą racjonalnej gospodarki złożami kopalin, tyle że wspomniany art. 11a pkt 1 dotyczy wyłącznie niektórych złóż objętych własnością górniczą. Z kolei nakaz racjonalnej gospodarki złożem dotyczy wszystkich złóż, bez względu na rodzaj kopaliny (art. 125 i 126 pr.o.ś. w zw. z art. 29 ust. 1 pr.g.g.). Sprawy gospodarki złożami kopalin nie obejmują natomiast problematyki podziemnego bezzbiornikowego magazynowania substancji (które zaliczane są do działu energia, objętego zadaniami Ministra Aktywów Państwowych) oraz podziemnego składowania dwutlenku węgla, aczkolwiek koncesje na wspomnianą działalność także wymagają uzgodnienia z ministrem właściwym do spraw gospodarki złożami kopalin.

Zbliżone wątpliwości dotyczą przesłanek, którymi mają kierować się pozostałe (pozagminne) organy orzekające w sprawach uzgodnień bądź opinii wymienionych $\mathrm{w}$ art. 23 pr.g.g. Co prawda niekiedy wynikają one z komentowanej ustawy (jak np. w odniesieniu do opinii Prezesa Wyższego Urzędu Górniczego, art. 23 ust. 1 pkt 1a) bądź przepisów kształtujących właściwość rzeczową organów współdziałających, tyle że ogólnikowość użytych tam określeń czasem może prowadzić do uznaniowości.

Koncesja starosty wymaga opinii z marszałkiem województwa (art. 23 ust. 3 pr.g.g.). Zdaniem M. Piątkowskiej rozwiązanie to „powinno służyć przede wszystkim przepływowi informacji pomiędzy organami administracji geologicznej, której właściwość w stosunku do części kopalin ustalono w sposób umowny (obszar do 2 ha, wydobycie do $20000 \mathrm{~m}^{3}$ ), co rodzi ryzyko naruszenia właściwości lub udzielenia koncesji w obszarze, na którym innemu podmiotowi udzielono już koncesji. Dodatkowo marszałek województwa, w przypadku

\footnotetext{
${ }^{18}$ Dz.U. 2019, poz. 945 ze zm.

19 Dz.U. 2019, poz. 2256.
} 
dostrzeżenia nieprawidłowości w projekcie koncesji starosty, może je wskazać w trakcie opiniowania, dzięki czemu w wielu przypadkach dochodzi do kształtowania się jednolitej wykładni lub praktyki w ramach województwa" ${ }^{" 20}$. Trafną jest ocena, że wspomniana opinia ma na celu zapobieżenie udzielenia koncesji starosty w odniesieniu do nieruchomości objętej już koncesją marszałka województwa. Zapewne dotyczyłoby to również postępowania koncesyjnego prowadzonego przez ten ostatni organ. Idąc tym tokiem rozumowania, należałoby jednak przewidzieć opinię starosty w postępowaniu koncesyjnym prowadzonym przez marszałka województwa. Zwrócić natomiast należy uwagę, że właściwość (kompetencja) organów koncesyjnych ustalona jest ustawowo, a nie umownie. Nie sposób zgodzić się też z oceną zakładającą, że funkcją opinii marszałka województwa jest wytknięcie ewentualnych nieprawidłowości, jakich mógłby dopuścić się starosta (w toku postępowania koncesyjnego). Rzecz jasna, nie ma przeszkód, by marszałek zwrócił uwagę staroście na dostrzeżone uchybienia, jednak podstawy takiego działania nie można upatrywać w art. 23 ust. 3 pr.g.g., lecz we wspomnianym już art. $7 \mathrm{~b}$ k.p.a. Trudność polega natomiast na tym, że użyty w tym ostatnim zwrot ,współdziałanie” nie dotyczy czynności podejmowanych $\mathrm{w}$ trybie art. 106 k.p.a. Rozwiązanie przewidziane w art. 23 ust. 3 pr.g.g. nie daje też odpowiedzi na pytanie, jak postąpić, jeżeli dwóch wnioskodawców w odniesieniu do częściowo tej samej przestrzeni ubiega się o koncesje na wydobywanie tej samej kopaliny objętej właściwością wspomnianych organów (starosty, marszałka województwa) i obydwa wnioski spełniają przewidziane wymagania. Podobne kolizje mogą pojawić się na etapie poszukiwania (rozpoznawania) złoża kopaliny, czyli w postępowaniach zmierzających do zatwierdzenia projektów robót geologicznych.

Problematyka przesłanek stanowisk zajmowanych w omawianym współdziałaniu przez organy pozagminne stała się przedmiotem rozstrzygnięć sądowoadministracyjnych. Co prawda dotyczą one dawnego stanu prawnego, jednak wypowiedziane tam poglądy częściowo nadal zachowują swoją aktualność. WSA w wyroku z dnia 6 czerwca 2006 r. przyjął, że odmowa uzgodnienia może nastąpić tylko na podstawie wskazanego wprost przepisu prawa (IV SA/ Wa 140/06), a w wyroku z dnia 9 czerwca 2006 r. (VI SA/Wa 839/06) wypowiedział pogląd, że uzgodnienie koncesji z ministrem właściwym do spraw gospodarki ${ }^{21}$ mieści się $\mathrm{w}$ ramach tzw. uznania administracyjnego. Nie oznacza ono jednak wcale zezwolenia na dowolne, arbitralne rozstrzyganie przez organ administracji publicznej, a także zwolnienia go z przestrzegania ogólnych reguł procedury administracyjnej oraz wymogu wnikliwego i logicznego uza-

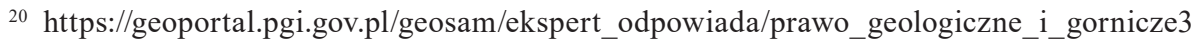
[dostęp: 31.03.2020].

${ }^{21}$ Pod rządem pr.g.g. 1994 koncesje na wydobywanie niektórych kopalin wymagały uzgodnienia z ministrem właściwym do spraw gospodarki. Obecnie art. 23 ust. 1 pkt 3 pr.g.g. wymaga uzgodnienia z ministrem właściwym do spraw gospodarki złożami kopalin. 
sadnienia zajętego w sprawie stanowiska. Wobec gwarantowanej Konstytucją swobody podejmowania działalności gospodarczej, która wprawdzie podlega pewnym ograniczeniom, ale tylko przy zaistnieniu bardzo szczególnych przesłanek, ograniczanie możliwości działalności przedsiębiorcy wymaga szczegółowego uzasadnienia. W wyroku z dnia 24 kwietnia 2008 r. (VI SA/Wa 178/07) przyjęto, że orzekając $\mathrm{w}$ przedmiocie uzgodnienia minister właściwy do spraw gospodarki musi działać na podstawie prawa i w jego granicach (art. 7 Konstytucji, art. 6 k.p.a.) oraz kierować się przesłankami wyznaczającymi zadania tego organu określone ustawą z dnia 4 września 1997 r. o działach administracji rządowej. Przedmiotem stanowiska wspomnianego ministra ma być ustalenie zgodności zamierzonej koncesji z uwarunkowaniami wyznaczającymi zakres pojęcia „sprawy gospodarki” bądź innemu ważnemu interesowi związanemu $\mathrm{z}$ tym działem. W istocie przesłanki te nabierają charakteru co najmniej częściowo uznaniowego.

W praktyce uzgodnienie koncesji należy do jednego z trudniejszych etapów postępowania, czego przyczyną jest przede wszystkim niejasny stan prawny, a także nikła świadomość prawna organów współdziałających przy udzielaniu koncesji. De lege ferenda należy zatem postulować radykalne uproszczenie omawianych rozwiązań, a przede wszystkim zmniejszenie liczby wymaganych uzgodnień oraz opinii.

Skutki uchybień obowiązkom w przedmiocie omawianego współdziałania są zróżnicowane. Tak więc podjęcie decyzji bez wymaganej opinii bądź dokonania uzgodnienia skutkuje wadliwością decyzji w stopniu uzasadniającym wzruszenie jej w drodze wznowienia postępowania (art. $145 \S 1$ pkt 6 k.p.a.). Inaczej należy natomiast oceniać podjęcie decyzji wbrew stanowisku organu współdziałającego. Skoro opinia nie ma charakteru wiążącego, podjęta niezgodnie z nią decyzja może być oceniona jako zgodna z prawem. Organ koncesyjny musi natomiast w uzasadnieniu wykazać, dlaczego orzekł wbrew takiemu stanowisku. Inny skutek pociąga za sobą koncesja podjęta $\mathrm{w}$ razie odmowy uzgodnienia. Ocenia się ją jako wydaną z rażącym naruszeniem prawa, co skutkuje jednak jej nieważnością. Stosowanie tych rozwiązań podlega jednak ograniczeniom w czasie (zob. art. 42 pr.g.g. oraz komentarz do tego przepisu).

Ogłoszenie stanu zagrożenia epidemicznego albo stanu epidemii z powodu COVID-19 wpływa na bieg terminów do dokonania uzgodnienia bądź zaopiniowania koncesji. W takiej sytuacji termin ten nie rozpoczyna się, a rozpoczęty ulega zawieszeniu na ten okres. Inaczej mówiąc, w razie zaistnienia opisanego wyżej stanu termin określony w art. 9 pr.g.g. nie biegnie. Jeżeli jednak w tym czasie postanowienie w przedmiocie współdziałania zostało wydane, jest ono skuteczne. W razie zagrożenia poważną szkodą dla interesu społecznego albo ze względu na grożącą niepowetowaną szkodę materialną organ koncesyjny może żądać, by organ współdziałający w wyznaczonym mu terminie zajął stanowisko w przedmiocie współdziałania, tj. odpowiednio orzekł w sprawie uzgodnienia 
bądź wyrażenia opinii (art. 15zzs ustawy z dnia 2 marca 2020 r. o szczególnych rozwiązaniach związanych z zapobieganiem, przeciwdziałaniem i zwalczaniem COVID-19, innych chorób zakaźnych oraz wywołanych nimi sytuacji kryzysowych $^{22}$ ). Wypada bronić zapatrywania, że w razie bezskutecznego upływu terminu określonego takim żądaniem, zachodzi skutek przewidziany w art. 9 ust. 2 pr.g.g.

\section{Literatura}

Agopszowicz A.: Zarys systemu prawnego górnictwa. Przejrzat i uzupetnit Aleksander Lipiński. Katowice 1991.

DoBRowOlsKi G.: Współdziałanie z organem wykonawczym gminy w postępowaniu koncesyjnym (na podstawie ustawy z dnia 9 czerwca 2011 r. Prawo geologiczne i górnicze). „Przegląd Ustawodawstwa Gospodarczego" 2011, nr 10, s. 14-22.

JaŚKowaK M., Wilbrandt-Gotowicz M., WróBel A.: Komentarz aktualizowany do Kodeksu postępowania administracyjnego. System Informacji Prawnej LEX, 2019 (wersja elektroniczna).

KACZMARSKI L.: Instytucja zajęcia stanowiska przez inny organ przy wydawaniu decyzji administracyjnej przez organ właściwy w sprawie. „Casus” zima 2018, nr 91, s. 27—41.

LIPIŃSKI A.: Miejscowy plan zagospodarowania przestrzennego jako źródło prawa. „Prawne Problemy Górnictwa i Ochrony Środowiska" 2017, nr 1, s. 34-54.

LIPIŃSKI A.: Niektóre problemy planowania przestrzennego w związku z działalnościa regulowana prawem geologicznym i górniczym. „Studia Iuridica Agraria” 2012, nr 10, s. 170-184.

LIPIŃSKI A.: Niektóre problemy wspótuczestnictwa organów administracji w procedurach regulowanych prawem geologicznym i górniczym. „Finanse Komunalne” 2013, nr 9, s. 64-68.

LiPIŃSKI A.: Ochrona złóż kopalin w świetle zasady zrównoważonego rozwoju. W: Právo na životné prostredie a nástroje jeho presadzovania. Zborník príspevkov z medzinárodnej vedeckej konferencie 6.-7. september 2016 Bojnice, Slovenská republika. Red. S. KošIČIARová. Trnave 2016.

LipIŃSKi A.: Prawne podstawy geologii i górnictwa. Warszawa 2019.

LIPIŃSKI A.: Współdziatanie w postępowaniu koncesyjnym prowadzonym na podstawie prawa geologicznego i górniczego. „Przegląd Ustawodawstwa Gospodarczego” 2005, nr 1, s. 2-12.

Lipiński A., Mikosz R.: Komentarz do ustawy Prawo geologiczne i górnicze. Warszawa 2003.

Mikosz R.: Granice koncesjonowania działalności regulowanej prawem geologicznym i górniczym. „Przegląd Prawa Ochrony Środowiska” 2009, nr 2, s. 39-58.

Prawo geologiczne i górnicze. Komentarz. Red. B. Rakoczy. Warszawa 2015.

MuRZYdŁo J.: Znaczenie miejscowego planu zagospodarowania przestrzennego $w$ świetle zmian wprowadzonych art. 7 ustawy z 9.06.2011 r. - Prawo geologiczne i górnicze. „Finanse Komunalne" 2013, nr 3.

Prawo przedsiębiorców. Komentarz. Red. A. Pietrzak. Warszawa 2019.

Schwarz H.: Prawo geologiczne i górnicze. Komentarz. T. 1. Wrocław 2013.

\footnotetext{
22 Dz.U. 2020, poz. 374 ze zm.
} 
Szydıo W.: Zakres władzy dyskrecjonalnej i współdziałania organów samorządu terytorialnego przy udzielaniu koncesji geologicznych i górniczych. „Samorząd Terytorialny” 2014, nr 11, s. $45-60$.

Wojtulek P., Kocowski T., Malecki W.: Prawo geologiczne i górnicze. Warszawa 2020.

Wybrane problemy prawa geologicznego i górniczego. Red. B. Rakoczy. Warszawa 2016.

WySzOMIRSKi Ł.M.: Glosa do wyroku NSA z dnia 22 października 2013 r., II GSK 1818/12. „Zeszyty Naukowe Sądownictwa Administracyjnego" 2014, nr 3, s. 167-176.

Źródła internetowe

Goss M.: Nadzór i regulacja sektora ropy i gazu. Warszawa 2016.

https://geoportal.pgi.gov.pl/geosam/ekspert_odpowiada/prawo_geologiczne_i_gornicze3 [dostęp: 31.03.2020].

Zrównoważony rozwój jako czynnik determinujący prawne podstawy zarządzania geologicznymi zasobami środowiska. Red. G. DobrowoLSKI. Katowice 2018. https://www.kpgios.us.edu. pl/attachments/article/231/Dobrowolski_Gospodarowanie_geologicznymi_zasobami_srodo wiska_w_swietle_zasady.pdf

Aleksander Lipiński

\section{Comment on art. 22-23 of Geological and Mining Act}

Summary

According to art. 22 of the GMA mining and geological licences, depending on the kind and place of the activity, are granted by the minister in charge of the environment, the head of the poviat or the marshal of the voivodship. The grant of the licence always must be preceded by cooperation with the authorities determined in art. 23 (like the President of National Atomic Energy Agency, the head of the local community, authorities responsible for the water management etc.). Depending on the kind of the licence or place of the activity, the „,cooperating authorities" are consulting the draft of the licence (opinion) or the draft has to be agreed with them. Unfortunately, in most situations the premises determining results of such cooperation are very unclear. The result of such cooperation may be controlled by the administrative court.

Key words: Geological and Mining Act, licenses, licensing authorities, co-operating authorities

Александр Липинський

\section{Комментарий к ст. 22-23 к закону о Геологическом и горном праве от 9 июня 2011 r.}

Резюме

Согласно ст. 22 Геологического и горного права, горные и геологические концессии, в зависимости от типа и места деятельности, предоставляются министром, ответственным за окружающую среду, старостой или маршалом воеводства. Присуждению кон- 
Komentarz do art. 22-23 ustawy z dnia 9 czerwca 2011 r. Prawo geologiczne i górnicze 61

цессий всегда должно предшествовать сотрудничество с органами, указанными в ст. 23 (например, президентом Национального агентства по атомной энергии, местными органами власти, органами власти, ответственными за управление водными ресурсами и т.д.) В зависимости от типа концессии или места деятельности, «взаимодействующие органы» дают консультацию по проекту концессии (заключение), или проект должен быть согласован с ними. К сожалению, в большинстве ситуаций условия, определяющие результаты такого сотрудничества, очень расплывчаты. Результат сотрудничества может контролироваться административным судом.

Ключевые слова: Геологическое и горное право, концессии, концессионные органы, взаимодействующие органы

Aleksander Lipiński

\title{
Commento agli art. 22-23 della legge del 9 giugno 2011 - Legge geologica e mineraria
}

\author{
Sommario
}

Riassunto: Ai sensi dell'art. 22 della legge polacca sulle attività geologiche e minerarie, a seconda del tipo e del luogo di attività, le concessioni minerarie e geologiche sono concesse dal ministro responsabile dell'ambiente, sindaco o maresciallo del voivodato. Il rilascio delle concessioni deve essere preceduto sempre dalla collaborazione con le autorità indicate all'art. 23 (come il Presidente dell'Agenzia Nazionale per l'Energia Atomica, le autorità delle comunità locali, le autorità responsabili della gestione delle acque, ecc.). A seconda del tipo di concessione o del luogo di stabilimento, le "autorità che cooperano" consultano il progetto di concessione (parere) o il progetto deve essere concordato con loro. Purtroppo, nella maggior parte delle situazioni, la logica dei risultati di tale cooperazione non è molto chiara. Il risultato di questa cooperazione può essere controllato da un tribunale amministrativo.

Parole chiave: Diritto geologico e minerario, concessioni, enti concessionari, enti cooperanti 